[Agr. Biol. Chem., Vol. 32, No. 3, p. 367 373, 1968]

\title{
Activation of Intracellular Proteinases of Yeast
}

\section{Part II. Activation and Some Properties of Pro-proteinase $\mathrm{C}^{*}$}

\author{
By Rikimaru HaYashi, Yoshinobu OKa, Etsushiro DoI \\ and Tadao HATA
}

Research Institute for Food Science, Kyoto University, Kyoto

Received September 18, 1967

\begin{abstract}
Pro-proteinase $\mathrm{C}$, the latent form of yeast proteinase $\mathrm{C}$, was partially purified from the autolysate of baker's yeast. It was strongly activated by incubation at $\mathrm{pH} 5$ or by treatment with urea or dioxane. The former activation was prevented by treatment to inactivate yeast proteinase $\mathrm{A}$, which co-existed with the pro-enzyme in the present preparation, but was promoted by addition of purified proteinase $A$. Thus, it was confirmed that A could activate pro-proteinase C. Furthermore, it was found that activation could be caused by extremes in $\mathrm{pH}$ or by heating to $55 \sim 60^{\circ} \mathrm{C}$, accompanied by the simultaneous destruction of the enzyme produced. Pro-proteinase $\mathrm{C}$ was stable over a range of $\mathrm{pH}$ 5 to 8 after $60 \mathrm{~min}$ incubation at $50^{\circ} \mathrm{C}$.
\end{abstract}

In the preceding papers, ${ }^{1,2}$ it has been suggested that, in intact cells of baker's yeast, most proteinases $\mathrm{B}$ and $\mathrm{C}$ occur in latent or zymogen forms, which are named as proproteinases $\mathrm{B}$ and $\mathrm{C}$, respectively. Their activation was brought about in vitro by incubation at $\mathrm{pH} 5$ or by treatment with certain denaturing agents, such as urea and several organic solvents. It has also been suggested that the former activation may be caused by the action of a specific enzyme present in the same extract.

In the present paper, the activation processes of pro-proteinase $\mathrm{C}$ are further investigated using the partially purified preparation. Some properties of this precursor are also described.

* This investigation was supported in part by a grant from the Japan Foundation of Applied Enzymology.

Abbreviations used in this paper: CGT, carbobenzoxy-L-glutamyl-L-tyrosine; A TEE, N-acetyl-L-tyrosine ethylester; HCl-Hb, acid-denatured hemoglobin.

1) R. Hayashi, Y. Oka, E. Doi and T. Hata, Agr. Biol. Chem., 31, 1102 (1967).

2) R. Hayashi, Y. Oka, E. Doi and T. Hata, ibid, 32, 354 (1968).

\section{MATERIALS AND METHODS}

Materials. CGT was purchased from the Institute for Protein Research, Osaka University, Osaka. Other chemicals used in this study were the same as in a preceding paper. ${ }^{2}$ Purified yeast proteinase A was prepared by the method described in a previous paper. ${ }^{3)}$ Dioxane was reagent grade and urea was recrystallized from $95 \%$ ethanol.

Determination of enzymatic activity. The activity of proteinase $\mathrm{C}$ was followed by measuring the esterase activity for ATEE with a Radiometer pH-stat as described in a preceding paper. ${ }^{2}$ In certain cases, the activity was determined by the peptidase activity for CGT in the following way. An assay mixture, containing $0.05 \mathrm{M}$ sodium acetate buffer, $\mathrm{pH} 5.0,3.3 \mathrm{~mm}$ CGT and $0.2 \mathrm{ml}$ of the enzyme solution, in total volume $1 \mathrm{ml}$, was incubated for $20 \mathrm{~min}$ at $25^{\circ} \mathrm{C}$ and immediately mixed with $2 \mathrm{ml}$ of ninhydrin solution prepared according to Stein and Moore.4) The mixture was heated in a boiling water bath for $20 \mathrm{~min}$, cooled, and after appropriate dilution, the absorbancy at $570 \mathrm{~m} \mu$ was determined in a Shimadzu QV-50 spectrophotometer.

3) T. Hata, R. Hayashi and E. Doi, Agr. Biol. Chem., 31, 357 (1967).

4) W. H. Stein and S. Moore, J. Biol. Chem., 176, 367 (1948). 
Quantitative assay of pro-proteinase $\mathrm{C}$ was routinely carried out by incubating the pro-enzyme in $0.01 \mathrm{M}$ sodium phosphate buffer, $\mathrm{pH} 7.0$, with one third volume of dioxane at $25^{\circ} \mathrm{C}$. After incubation for 15 min, an aliquot was withdrawn and immediately assayed for activity of proteinase $\mathrm{C}$.

The activity of proteinase $\mathrm{A}$ was determined as described previously.3)

Partial purification of pro-proteinase $C$. The crude extract of pro-proteinase $\mathrm{C}$ was prepared by autolysis of baker's yeast as described in the preceding paper ${ }^{2}>$ and partial purification of the pro-enzyme was performed as follows. The crude extract was dialyzed against $0.01 \mathrm{M}$ sodium phosphate buffer, $\mathrm{pH}$ 7.0 , at $5{ }^{\circ} \mathrm{C}$ overnight and $30 \mathrm{ml}$ of the dialyste was applied on a DEAE-cellulose column $(1 \times 7 \mathrm{~cm})$, equilibrated with the buffer as was used in the dialyzing solution. After washing the column with the same buffer, elution was performed by $0.01 \mathrm{M}$ sodium phosphate buffer, $\mathrm{pH} 7.0$, containing $0.2 \mathrm{M}$ sodium chloride. The first $3 \mathrm{ml}$ of the eluate were discarded and the next $10 \mathrm{ml}$ of the eluate were collected. Since the pro-proteinase $\mathrm{C}$ in this preparation was gradually activated, even standing at $\mathrm{pH} 7$, the sample was prepared on the day of the experiments.

In the experiments on $\mathrm{pH}$ - and heat-stability of pro-proteinase $\mathrm{C}$, the crude extract was previously incubated at $\mathrm{pH} 8.5$ for $2 \mathrm{hr}$ at $25^{\circ} \mathrm{C}$ in order to inactivate proteinase $\mathrm{A}$ present in the extract, followed by dialysis and chromatography on a DEAEcellulose column. The eluate from the column was fractionated with ammonium sulfate and the precipitate, which produced between $60 \sim 800^{\circ}$ saturation of ammonium sulfate, was collected and desalted by gel-filtration on a Sephadex G-25 column. The resulting preparation of pro-proteinase $\mathrm{C}$ contained no detectable activity of proteinase $A$ and the activation of pro-proteinase $\mathrm{C}$ was little or negligible while standing at pH 5 overnight.

Determination of protein concentration. Protein concentrations were determined by the method of Lowry et al. s) $^{2}$

\section{RESULTS}

\section{1) Activation by Urea and Dioxane}

The Pro-proteinase $\mathrm{C}$ used in these experiments was strongly activated by dioxane and urea, a maximum activation being obtained

5) O. H. Lowry, N.J. Rosebrough, A. L. Farr and R. J. Randall, J. Biol. Chem., 193, 265 (1951). when the pro-enzyme was incubated with $3 \mathrm{~m}$ concentration of urea for $60 \mathrm{~min}$ or with $33 \%$ $(\mathrm{v} / \mathrm{v})$ concentration of dioxane for $15 \mathrm{~min}$. The activation by urea was sharply dependent upon pH with its optimum at pH 5. However, the activation to the same degree by dioxane was observed over a range of $\mathrm{pH} 5$ to 8 . These properties were the same as those in the crude extract.

\section{2) Activation by Incubation at Various $\mathrm{pH}$}

The activation of pro-proteinase $\mathrm{C}$ was dependent on $\mathrm{pH}$ and maximum activation was obtained when the crude extract was incubated at pH 5 overnight. ${ }^{2)}$ However, these expuriments may not reveal an accurate $\mathrm{pH}$-dependency of the activation, since the proteinase $\mathrm{C}$ produced, which is very labile below $\mathrm{pH} 4,{ }^{6}$ may be accompanied by simul-

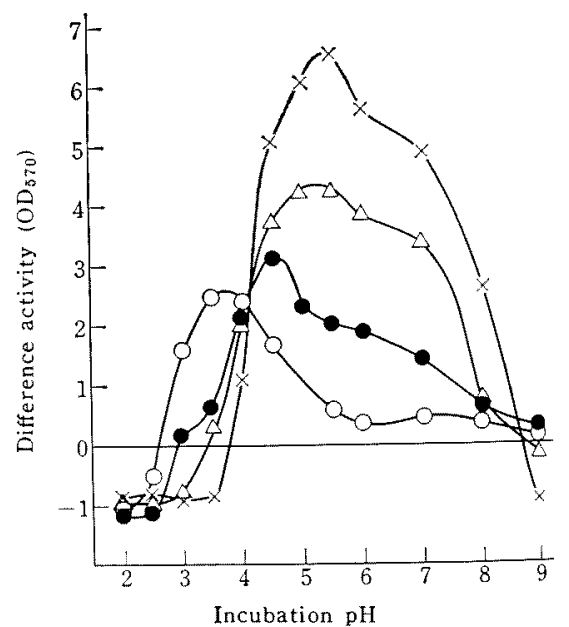

FIG. 1. Effect of $\mathrm{pH}$ on the Activation of Proproteinase $\mathrm{C}$.

Pro-proteinase $\mathrm{C}(1.3 \mathrm{mg})$ was incubated with $4 \mathrm{ml}$ of $0.05 \mathrm{M}$ buffer solution (lactate, $\mathrm{pH} 2.0 \sim$ 3.0 ; acetate, $\mathrm{pH} 3.5 \sim 5.5$; phosphate, $\mathrm{pH} 6.0 \sim$ 7.5 ; borate, $\mathrm{pH} 8.0 \sim 9.0$ ) at $37^{\circ} \mathrm{C}$. An aliquot of each mixture was withdrawn at various intervals and immediately assayed for peptidase activity of proteinase $\mathrm{C}$ using $\mathrm{CGT}$ as the substrate. Incubation time:

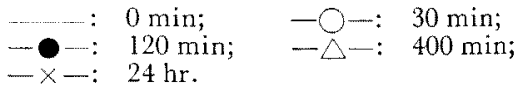

6) E. Doi, R. Hayashi and T. Hata, Agr. Biol. Chem., 31, 160 (1967). 
taneous inactivation during a long incubation at an acidic $\mathrm{pH}$. So, time dependency of the activation was tested as function of $\mathrm{pH}$. The results are presented in Fig. 1. At pH 3 to 4 , a rapid activation was observed but some inactivation seemed to occur at the same time. With incubation time, the peak of activity moved to a higher $\mathrm{pH}$ and reached $\mathrm{pH} 5$ after $24 \mathrm{hr}$. Time courses of the activation at various $\mathrm{pH}$ levels are presented in Fig. 2.

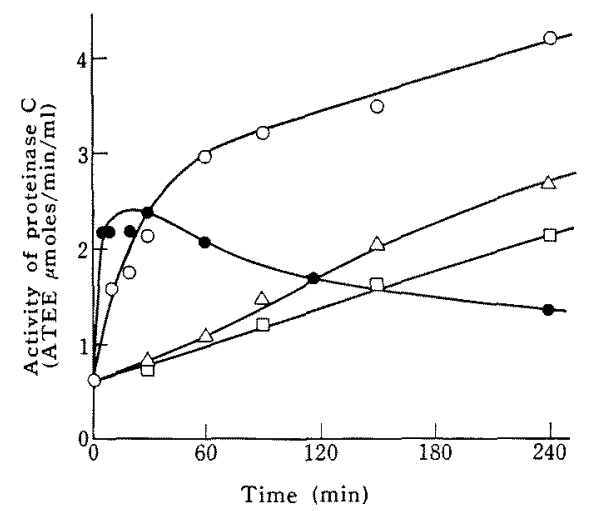

FIG. 2. Time Courses of the Activation of Proproteinase $\mathrm{C}$ at Various $\mathrm{pH}$ Values.

Pro-proteinase C $(500 \mu \mathrm{l}, 890 \mu \mathrm{g})$ was incubated with $1 \mathrm{ml}$ of $0.05 \mathrm{M}$ buffer at $37^{\circ} \mathrm{C}$. The activity of proteinase $\mathrm{C}$ was determined with esterase activity as described in the text. The other experimental conditions are the same in Fig. 1. Incubation $\mathrm{pH}$ :

-1 pH 3; $-\bigcirc-:$ pH 4 ;

On incubation at $\mathrm{pH} 3$ or 4 , the activity rapidly appeared in initial stage of incubation and was followed by decrease or supression probably due to irreversible inactivation of the activated enzyme. On incubation at $\mathrm{pH}$ 5 or 7 , the activation proceeded linearly, with a faster rate than that of the crude extract. ${ }^{21}$ As described below, the activation which occurred around $\mathrm{pH} 3$ was a different process from that around $\mathrm{pH}$ 5. Probably the former activation was catalyzed by hydrogen ions and the latter by the proteinase A co-existing in the same preparation.

\section{3) Activation by Yeast Proteinase A}

It has been suggested ${ }^{1,2)}$ that the activation of pro-proteinase $\mathrm{C}$ during incubation at $\mathrm{pH} 5$ is catalyzed by a specific enzyme as in the case of the well-known proteinase zymogens. Since the present preparation of pro-proteinase $\mathrm{C}$ contains proteinase $\mathrm{A}$, the effect of the latter enzyme on the activation of pro-proteinase $\mathrm{C}$ was tested. As shown in Fig. 3, the activation

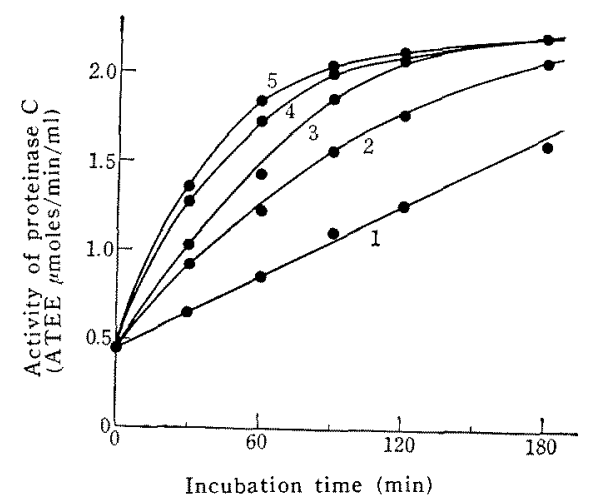

FIG. 3. Effect of Yeast Proteinase A on the Activation of Pro-proteinase $\mathrm{C}$.

Pro-proteinase $\mathrm{C}(360 \mu \mathrm{g})$ was incubated with $400 \mu \mathrm{l}$ of sodium acetate buffer $(0.1 \mathrm{M}, \mathrm{pH} 5.0)$ and specified amounts of purified proteinase $A$ in a total volume of $800 \mu l$ at $25^{\circ} \mathrm{C}$. An aliquot was withdrawn at various intervals and immediately assayed for the activity of proteinase $C$.

Amounts of proteinase A added: none, 50.4, $100.8,151.2$ and $201.6 \mu \mathrm{g}$ for the curve 1 to 5 , respectively.

rate was increased by addition of increasing amounts of purified proteinase A. The transformation to the active state during incubation with A seemed to be complete after $2 \mathrm{hr}$ under the conditions given in Fig. 3 , as the activity obtained under these conditions was proportional to the amount of pro-proteinase $\mathrm{C}$, as shown in Fig. 4. On the other hand, activation was not brought about by addition of purified proteinase $\mathrm{C}$, but a slight activation was observed with the addition of crystalline trypsin. The experiments in Figs. 5 and 6 also show that proteinase A causes 


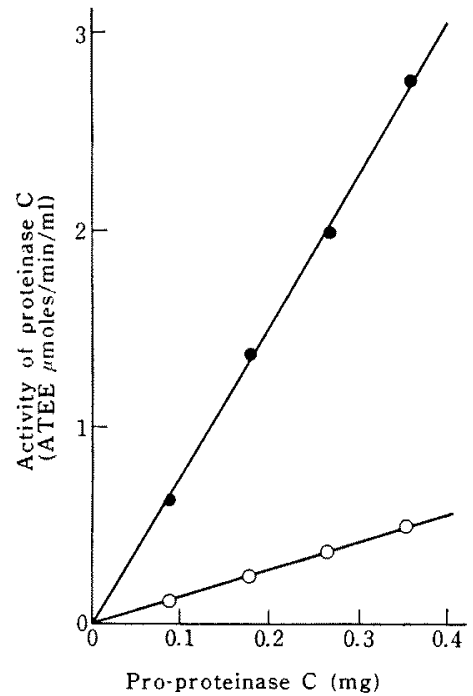

FIG. 4. Relationship of Varying Amounts of Proproteinase $\mathrm{C}$ and Activity after Full Activation by A.

Varying amounts of pro-proteinase $\mathrm{C}$ were mixed with $200 \mu$ l sodium acetate buffer $(0.1 \mathrm{M}, \mathrm{pH} 5)$ and purified proteinase A $(200 \mu \mathrm{g})$ in a total volume of $600 \mu \mathrm{l}$ and incubated at $37^{\circ} \mathrm{C}$ for $2 \mathrm{hr}$. An aliquot was withdrawn and immediately assayed for the activity of proteinase $C$.

- - -: Activity before the activation

--: Activity after the activation.

activation of pro-proteinase $\mathrm{C}$ when the yeast extract is incubated at $\mathrm{pH} 5$. The partially purified pro-proteinase $\mathrm{C}$ was adjusted to various $\mathrm{pH}$ values and incubated at $25^{\circ} \mathrm{C}$ for $2 \mathrm{hr}$. Then, an aliquot of each reaction mixture was withdrawn and activated by incubation at $\mathrm{pH} 5$ with and without the addition of purified A. Thereafter, the activity of proteinase $\mathrm{C}$ was compared before and after activation. The results are presented in Fig. 5. In the first incubation at various $\mathrm{pH}$ values, the activity of proteinase $\mathrm{C}$ in the reaction mixture showed little variation over the wide $\mathrm{pH}$ range tested, but $\mathrm{A}$ was extensively inactivated as the incubating $\mathrm{pH}$ was raised from $\mathrm{pH} 8$ to 9 . When activation was carried out without addition of $\mathrm{A}$, the appearance of activity of $\mathrm{C}$ was suppressed in parallel with

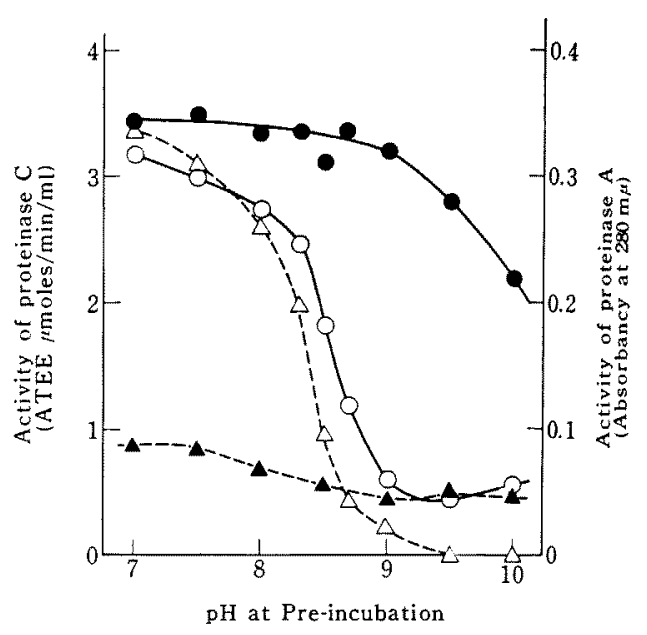

FIG. 5. Effect of Preincubation at Alkaline pH Levels on the Activation of Pro-proteinase $\mathrm{C}$.

Pro-proteinase $\mathrm{C}(1.78 \mathrm{mg} / \mathrm{ml})$, adjusted to various $\mathrm{pH}$ values, was incubated at $25^{\circ} \mathrm{C}$ for $2 \mathrm{hr}$. An aliquot was withdrawn, mixed with an equal volume of sodium acetate buffer $(0.1 \mathrm{M}, \mathrm{pH} 5.0$ ) and the activation was carried out with and without addition of purified proteinase $\mathrm{A}(71.2 \mu \mathrm{g})$ at $37^{\circ} \mathrm{C}$ for $4 \mathrm{hr}$.

$\cdots \triangle-\cdots, \cdots-\cdots$ Activity of proteinases $A$ and $\mathrm{C}$ before the activating treatment, respectively; - - , - - - Activity of proteinase $\mathrm{C}$ after the activation with and without addition of proteinase $A$, respectively.

the inactivation curve for A present in the mixture. However, when activation was performed with the addition of $\mathrm{A}$, it showed a significant occurrence over a wide $\mathrm{pH}$ range. As shown in Fig. 6, the proteinase A present in the preparation was almost completely inactivated when pre-incubation was carried out at $\mathrm{pH} 8.5$ for $2 \mathrm{hr}$, and consequently activation of pro-proteinase $\mathrm{C}$ was prevented unless purified $\mathrm{A}$ was added.

Thus, it may be expected that activation of pro-proteinase $\mathrm{C}$ during incubation at $\mathrm{pH}$ 5 is brought about by the action of proteinase A present in the preparation and that this activation can be prevented if the co-existing proteinase $A$ is destroyed by previous incubation at $\mathrm{pH} 8.5$ for $2 \mathrm{hr}$. 


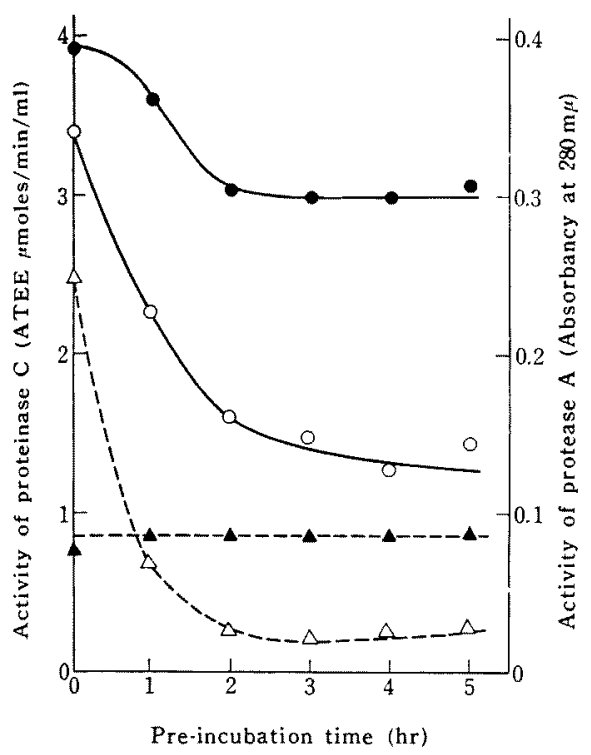

FIG. 6. Effect of Preincubation at $\mathrm{pH} 8.5$ on the Activation of Pro-proteinase $\mathrm{C}$.

Pro-proteinase $\mathrm{C}(1.78 \mu \mathrm{g} / \mathrm{ml})$ was incubated at $\mathrm{pH} 8.5$ and $25^{\circ} \mathrm{C}$. An aliquot withdrawn at various intervals was mixed with an equal volume of sodium acetate buffer $(0.1 \mathrm{M}, \mathrm{pH} 5.0)$ and the activation was carried out with and without addition of proteinase $\mathrm{A}(35.6 \mu \mathrm{g})$ at $37^{\circ} \mathrm{C}$ for 4 hr. Symbols are the same as in Fig. 5.

\section{4) Stability of Pro-proteinase $C$}

The stability curves of pro-proteinase $\mathrm{C}$, as a function of $\mathrm{pH}$ and temperature, are shown in Figs. 7 and 8, respectively, where the activity was measured immediately before and after activation by dioxane under conditions described in the figures. When pro-proteinase $\mathrm{C}$ was allowed to stand at various $\mathrm{pH}$ values for $60 \mathrm{~min}$ at $25^{\circ} \mathrm{C}$, spontaneous activation was observed to occur extensively at pH 3 and slightly above pH 9, whereas no detectable changes took place between pH 5 and 8 . Since activity of proteinase $A$ in the present preparation was negligible, the activation at $\mathrm{pH} 3$ seemed to be catalyzed by hydrogen ions but not by A. This estimation was confirmed by the fact that the activation was not accelerated by the addition of purified proteinase $\mathrm{A}$. The activation at an alkaline $\mathrm{pH}$ might be caused by hydroxide ions. On the other hand, activation by dioxane gave the same degree of activity over the wide range

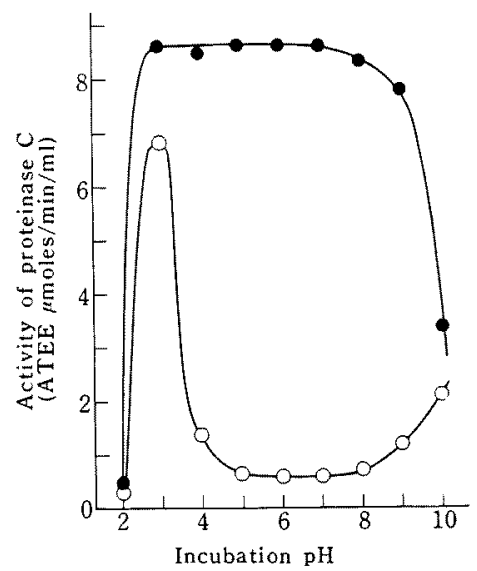

FIG. 7. pH-Stability of Pro-proteinase C.

Pro-proteinase C $(120 \mu \mathrm{g})$ which was prepared after the previous inactivation of proteinase $A$, was incubated with $100 \mu \mathrm{l}$ buffer $(0.02 \mathrm{M})$ in a total volume of $200 \mu \mathrm{l}$ at $37^{\circ} \mathrm{C}$ for $60 \mathrm{~min}$. Buffers used were the same as in Fig. 1. An aliquot was mixed with an equal volume of sodium phosphate buffer $(0.1 \mathrm{M}, \mathrm{pH} 7.0)$ and activated with dioxane (final conc., $330 \%(\mathrm{v} / \mathrm{v})$ ) for $15 \mathrm{~min}$.

- - -: Activity before the activation

- - Activity after the activation.

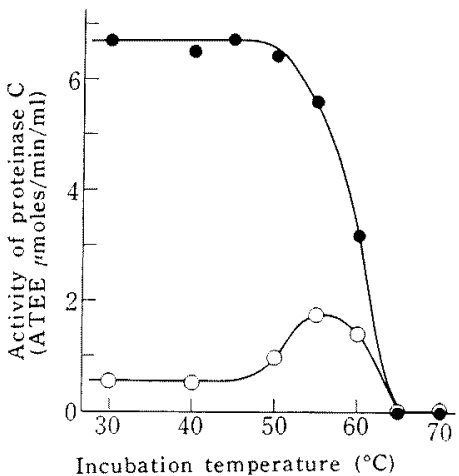

FIG. 8. Heat-Stability of Pro-proteinase C.

Pro-proteinase C $(143 \mu \mathrm{g})$ was incubated with $400 \mu 1$ sodium phosphate buffer $(0.02 \mathrm{M}, \mathrm{pH} 6.0)$ in a total volume of $500 \mu$ at various temperatures for $60 \mathrm{~min}$ and immediately cooled. Other experimental methods and symbols are the same as in Fig. 7. 
of $\mathrm{pH} 3$ to 8 . Therefore, taking into consideration spontaneous activation at acid and alkaline $\mathrm{pH}$ values, pro-proteinase $\mathrm{C}$ appears to be stable on the incubation between $\mathrm{pH} 5$ and 8 at $25^{\circ} \mathrm{C}$, at least for $2 \mathrm{hr}$. As shown in Fig. 8, pro-proteinase $\mathrm{C}$ was stable in incubation at $\mathrm{pH} 6$ and $50^{\circ} \mathrm{C}$ for $60 \mathrm{~min}$. However, slight activation seemed to occur spontaneously between $50 \sim 60^{\circ} \mathrm{C}$.

\section{DISCUSSION}

Partially purified pro-proteinase $\mathrm{C}$ was greatly activated by allowing it to stand at various $\mathrm{pH}$ values, gradually activated at $\mathrm{pH} 5 \sim 7$ and rapidly at $\mathrm{pH} 3 \sim 4$. Activation at $\mathrm{pH} 5 \sim 7$ was prevented by treatments to inactivate the activity of proteinase $\mathrm{A}$ which co-existed in the preparation, whereas its activity was promoted by addition of purified yeast proteinase A. These results show that A catalyzes the transformation of pro-proteinase $\mathrm{C}$ to proteinase $\mathrm{C}$ at $\mathrm{pH} 5 \sim 7$. Although the apparent optimum $\mathrm{pH}$ of $\mathrm{A}$ is between $\mathrm{pH} 2$ and 3; toward casein and $\mathrm{HCl}-\mathrm{Hb}$, respectively, ${ }^{71}$ the enzyme may act at a higher $\mathrm{pH}$ according to the kind of the substrate proteins, as with pepsin. ${ }^{8 !}$ More rapid activation at $\mathrm{pH} 5 \sim 7$ of the present preparation than for that of the crude extract may be explained by the possibility that the removal of contaminating proteins facilitates the action of A toward pro-proteinase C. Since rapid activation at $\mathrm{pH} 3$ could be brought about after removal of $\mathrm{A}$ and was not promoted by its addition, the results confirmed that this activation is caused by acid but not by $\mathrm{A}$.

These activation processes of pro-proteinase $\mathrm{C}$ seem to be basically similar to those of prorennin $^{31}$ and pepsinogen. ${ }^{101}$ Their trans-

7) T. Hata, R. Hayashi and E. Doi, Agr. Biol. Chem., 31, 150 (1967).

8) M. Schlamowitz and L. U. Peterson, J. Biol. Chem., 234, 3137 (1959).

9) H. F. Bundy, N. J. Westberg, B. M. Dummel and C. A. Becker, Biochemistry, 3, 923 (1964); B. Foltmann, Compt. Rend. Trav. Lav. Carlsberg, 35, 143 (1966). formation to active enzymes is brought about by hydrogen ions or by limited proteolysis which proceeds autocatalytically. Activation by exposure to acid has been often described for enzymes other than the above zymogens. Latent phenolase ${ }^{11,121}$ from broad-bean leaves can be activated by brief exposure to $\mathrm{pH}$ $3 \sim 3.5$. Vogels ${ }^{131}$ has described that allantoate amido hydrolase is reversibly activated by acid-pretreatment below $\mathrm{pH} 4.5$. In these two cases, it has been suggested that the transformation of latent forms to active states is not associated with the dissociation and association process of a certain masking peptide.

Pro-proteinase $\mathrm{C}$ in the present preparation was also activated rapidly by treatment with urea or dioxane and slightly activated by exposure to alkaline $\mathrm{pH}$ or by heating between $50 \sim 60^{\circ} \mathrm{C}$. From the fact that all these activations occurred in the absence of $A$, the possibility may be ruled out that these treatments make the inhibitor susceptible to $A$, and hence that the activation is caused by proteolytic digestion of the inhibitor by $A$. Thus, all these treatments seem to cause either a certain structural alteration of the precursor or the direct destruction of a bound inhibitor, which leads to the active form.

The molecular dimensions of the active and inactive forms of pro-proteinase $\mathrm{C}$ were estimated by gel-filtration on a Sephadex G100 or G-200 column. Both forms were eluted simultaneously and showed no changes in their molecular dimensions. However, the results may not be necessarily valid, as differences in sugar content of the active and inactive forms ${ }^{31}$ may not reflect accurately the mole-

10) F. A. Bovey and S. S. Yanari, "The Enzymes," Vol. 4 , ed. by P. D. Boyer et al., Second ed., Academic press, 1960, p. 63.

11) R. H. Kenten, Biochem. J., 67, 300 (1957).

12) D. A. Robb, L. W. Mapson and T. Swain, Nature, 201, 503 (1964).

13) G. D. Vogels, Biochim. Biophys. Acta, 113, 277 (1966). 
cular dimension of each form on gel-filtration, date the chemical and physical nature involvas indicated by Andrews. ${ }^{141}$ In order to eluci- ed in the activation process of pro-proteinase 14) P. Andrews, Biochem J., 96, 595 (1965). $\mathrm{C}$, it is necessary to perform a further purification of the pro-enzyme. 